\title{
SUSTAINABLE RURAL DEVELOPMENT AND THE EFFECTS OF EDUCATION, DEMOGRAPHY AND ACCESS IN THE AGRICULTURAL SECTOR STRUCTURE AND EFFICIENCY
}

\author{
Alda Miftari ${ }^{1}$, Arta Musaraj $^{2}$
}

\begin{abstract}
The correlation between Education and Development has been widely investigated under the point of view of Economics, referring to the labour-intensive sectors and effects on their efficiency, as well as in the Social Sciences point of view, by focusing on the characteristics of the rural population, structure and cohesion, gender issues and the output it has on the development of agriculture in a given area. Referring to access policies into Agri-environmental schemes we will discuss the adoption of new technologies for sustainable rural development, environmental enhancement of the farm and the caution laissez-faire attitude to environmental protection. The data set selected for elaboration on this article are produced by the ISTAT institute on tome series from 2010 to 2015 . Attention in this paper was focused on whether education level, age and gender has influenced social policies and the decision-making of producer policies. The results of this research are to investigate and affect factors on agricultural development by proposing a specific framework of analysis and interpretation including correlations existing between age, education and farmer contractors, demographic density changes and the empirical approaches, adopted by rural sociologist.
\end{abstract}

UDC Classification: 711, DOI: 10.12955/cbup.v7.1410

Keywords: farmers education, farmers training, farmers age, access policies in agricultural subventions, sustainable rural development, environmental issues.

\section{Introduction}

Over the last decades development issues and the process of evolution in rural activity or farming has faced an increased emphasis on rural area. This process seeks progress on social change and sustainable economic development for rural community's ongoing relevance on environmental change. Farmers' education affects significantly the farming activity itself, and at the same time it represents a tool to improve the economic, political and social situation of farmers themselves. Furthermore, farmer's education has a significant influence on the progress, conservation and care for the environment. As Burton (2006) writes, the influence that farmers' have on environmental behavior include age, education, experience and gender. These personal features are measured because they influence the choices people make, and consequently provide an indication of how one group of farmers (e.g. older, female, less experienced, better educated) will behave given a delicate circumstance. We need to figure out how the influence of farmers could affect economic growth, improving social conditions and workers' conditions according to a bottom-up approach, through the participation and the investigation of the intergenerational impact of farmers' educational attainment on rural development (Alphonsus \& Sabran, 2016). Sustainable Rural Development (SRDP) can be defined as a process of multidimensional change affecting the existence of the social and ecological conditions necessary to support human life at a certain level of well-being through future generations (Earth-Council, 1994). Sustainable Rural Communities should integrate and internalise the process of cohesion on integrity policies, improving training on environment knowledge, adopting new technology opportunity, properly integrating them for preserving and protecting the environment (Chiodi, 2018). However, the identification of factors with relevance over the cohesion between education and actual participation is one of the purposes of this paper. The same goes for the investigation of the connections between age and the level of education and the impact they both have on the overall economic level of farmers in different areas of Italy. Some scholars argue that conceptualizing rural behaviour of the group which farmers belong to has different attitudes and aims on educational level, age and financial incomes Miftari (2019). This research will investigate the relationship between education, age and behaviour on farmers' choice to participate in European financiered programmes for young farmers. In specific the strategy of young farmers will be investigated. Our interest is to show how those variables influence the welfare of farmers on agriculture activity and which is the access on financial contribution they perceive in different Regions of Italy from the European Commission. A political assessment has been discussed and implemented by the European Community. Illiteracy, the well-organized contribution of farmers and the implementation of environmental policies from the government are some of common problems affecting the challenges in

\footnotetext{
${ }^{1}$ Department of Applied Social Sciences and Economics, Sapienza University of Rome, Italy, alda.miftari@uniroma1.it

${ }^{2}$ Entrepreneurship Training Center, Albania, ceo@etc.edu.al
} 
the Sustainable Agriculture and Rural Development (SARDP) process in the Italian Region (FAO, 1999). Rural Development (RDP) manage and facilitate the access of farmers promoting innovative techniques for young farmers between the ages of 18 and 40 who are owners of an individual business or a farm. This programme under the Rural Development Programme (RDP) 2014-2020 is financed from the European Community "Support for local development" Rural Development Programme (RDP, 2015). We will investigate over a large scale of ages the so-called "young farmer" that is extended from 35 to 65 years old, as well as discuss which are the policies and the options to increase productivity in farming approaches in the social and environmental local context.

\section{Literature review}

Farmers' education requires ongoing innovation for increasing the knowledge for the development of technology tools into their daily operations, management, promoting the environment and all the other fields that affect agricultural operations, and increase the profit margin of farm income without sacrificing the quality of life i.e. food. Agriculture has a significant pressure on natural resources (water, land) and intends to be sustainable for protecting the environment and the society (Daci, 2012). Sustainable agriculture is defined, as the ability of farmland to produce food and other agricultural products to satisfy human needs indefinitely as well as having sustainable impacts on the broader environment (Pugliese, 2001; Moini, 2012). Sustainable agriculture is a broad issue. It includes considerations of productivity goals; environmental stewardship; farm profitability and rural welfare objectives as well as consumer health; enhance the quality of life for farmers and society (Michael, 2016; Moon, Marshall, \& C, 2012; Michael, 2016). The social behaviour of farmers toward a greater sustainable awareness and the care on land production and conservation is correlated with the level of education and age (Burton \& Wilson, 2006; McGuire, Morton, Gordon, \& Cast, 2015). Regarding age (Zagata \& Sutherland, 2015) writes that the $35-<45$ years age group, which is the focus of European policy, generate more value for agriculture than their older counterparts, and therefore may indeed be part of the driving force for the Rural Development, rightly hoped for by the European Commission. The implementation of recent reforms of the European Union's (EU) Common Agriculture Policy (CAP) focused on making agriculture more sustainable and market-oriented (European Commission, 2015). The young farmers are defined by the EU as less than 40 years old, who receive subsidies from European contributions. Of course, the greater involvement of the European Union is needed for the new entrants to farming, as entrepreneurial innovators approving to and amenable with the goals of the CAP (Hamilton, Bosworth, \& Ruto, 2015). The European Commission has identified the declining of number of farmers in the European Union, especially in Italy. Since the early 90's the European Commission in collaboration with agriculture and Rural Development started the new agreement on Cap reform reached in 2013 (Gravsholt \& Brusck, 2002). It refers to the following considerations:

- Price (exports have distorted the markets due to globalization)

- Factors of production

- Commercial accomplishments

Following the publications of proposals of the CAP reform, all eligible young farmers will receive European Contributions (EC, 2013). Other academics think that the trend of age should not be considered as the main indicator of farm performance or management practice, even though they are more open to change, be more technological and sustainable, and play a very important role in agriculture decision making (Ondersteijn et al., 2003; Zeneli, 2016). In this context, we have analysed for different regions in Italy how the age of farmers influences the social dimension of the agriculture sector and the positive strategy of the orientation of sustainable agriculture.

One of the important indicators taken into consideration is the level of instruction on the age of farmers. In this paper, we critique the assessment made by the EC regarding the age of farmers as a unique indicator of considering the "young farmers" from 35 to 45 years old on the agriculture sector. Our work will examine future farming on the regional level in Italy but could be taken into consideration in EU level too, considering the "age of farming" from 35 to 65 years old - as the most active age on efficient agriculture and the most potential group on developing and preserving their own experiences in the long term.

\section{Data and Methodology}

The National Institute of Statistics in Italy ISTAT conducts every 10 years a survey on a national level on the agriculture sector. The last survey was conducted in 2010 . We have elaborated the data and we 
have shown the correlation between age and level of education. The division on five geographical regions in Italy have the scope to show more clearly the concentration of the percentage of age of the farm manager (De Rosa et al., 2013). The region with a higher percentage of farm managers is the NorthWest region of Italy $62 \%$. It is important to mention the reason why our data is divided in three groups of ages; first group - less than 34 years old - this group of farmers is the lowest group in all the country, confirming the assumption that the number of youngest farmers is very low. The second and largest group and the most important is the analysis of distribution of farmers in the age between 35 to 64 years old, the most active and more interested in the agriculture field. It is important to show this concentration of farmers in this group of age and try to bring forward some challenges while remaining coherent with other EU policies. The enhancement and improvement of the EU contribution in supporting and encouraging producers is expected to influence development and growth processes (McCann et al., 1997). The young farmers in general are concentrated on achieving social and environmental aims instead of being oriented towards their farm business development (Zagata \& Sutherland, 2015). On the other hand, Fuentes et al., 2010 and Dias and Franco, 2018 are concerned that the social and economic aspects of a rural farm based on entrepreneurship are becoming of interest of the "age of farming". Zagata and Southerland (2015) found that new entrants, rather than younger farmers per se, were more likely to be involved in value-added farming activities (e.g. alternative agri-food networks, local certification schemes), capitalising upon their urban network and experience. The income of farmers is low, and it is difficult to have precise data about this issue. ISTAT estimates show that agricultural households have a per capita average expenditure lower than families in which the reference person is employed in other sectors of activity (ISTAT, 2019). The problem of income, even if reduced compared to the time when Common Agricultural Policy (CAP) was implemented, therefore seems to exist in Italian agriculture, in particular with the presence of some areas of poverty among agricultural families (Rocchi, Stefani, \& Romano, 2012). This is the reason why we decided to put together a large group of farmers into the same cluster (35-65 years old), representing in this term the recreationally and multifunctionality of new-old farmers so called from Miftari (2019) "age of farming". The last group of distribution shows the distribution of farmers from 65 years and over. This percentage is almost considerable and important on the agriculture sector for the Italian regions mostly for the role and the attitudes of historical development and culture, which are characterized (Best, 2009). The correlation between age and education has retained a salience and currency in contemporary society in addition to having played a prominent role not only for farmers' lives but having an important role in the historical development of the Italian country.

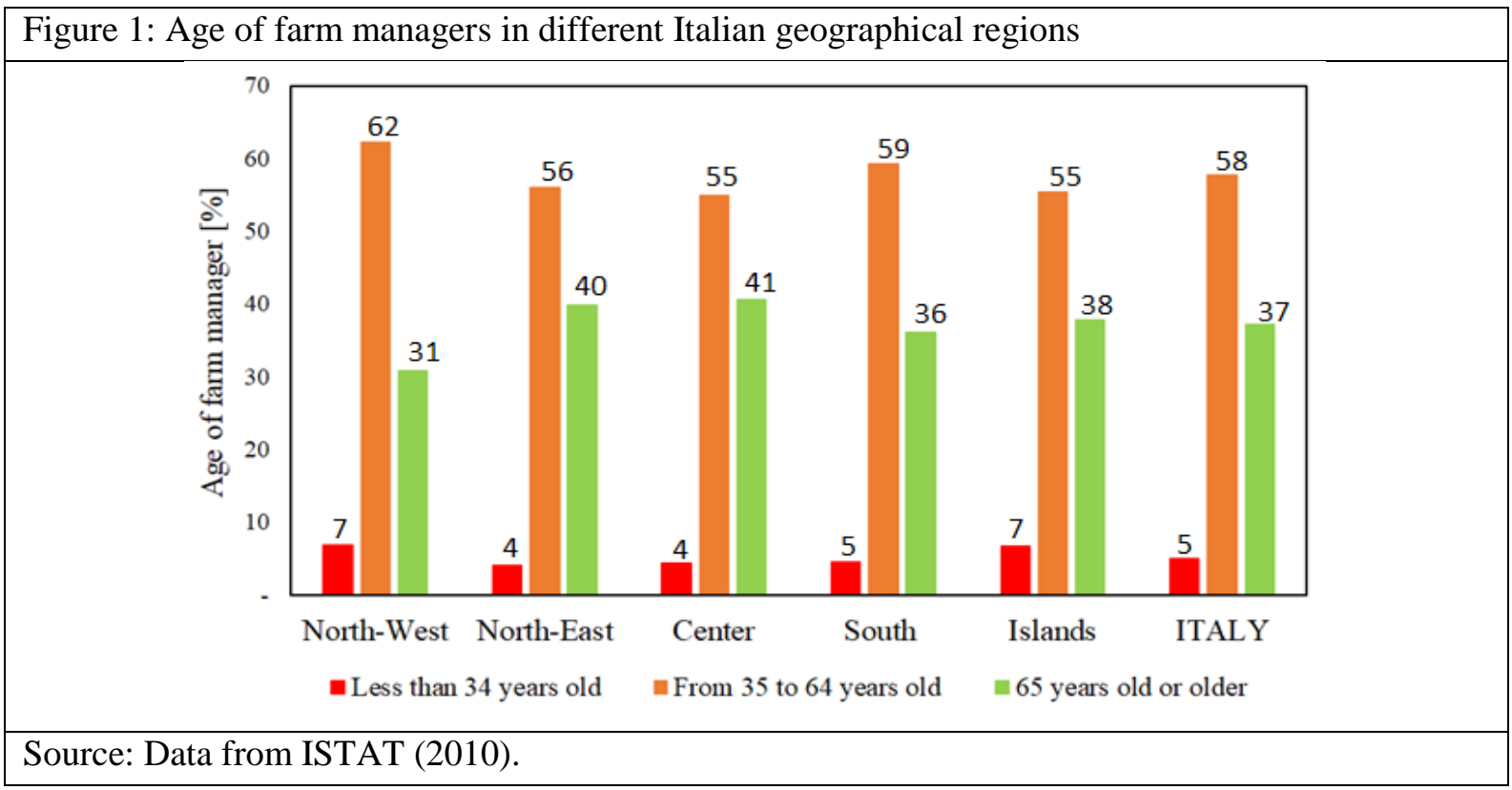

From a summary of the main results realized from the $6^{\text {th }}$ survey of Agriculture made by ISTAT, it is seen that the number of farms decreases from the year 2000 to 2010 (ISTAT, 2019). About $99 \%$ of farms operate on family labor and $30.7 \%$ of the company leaders are female. The total number of farmers in 
Italy is $1,620,884$. For instance, the first group of farmers less than 34 years old amount to 82,111 farmers which when expressed in percentage is 5\%. The second age group from 35-65 amount to 93,538,700 farmers which when expressed in percentage is 58\% and the last age group, 65 and over, amount to 603,386 farmers which when expressed in percentage is $37 \%$. A statistical comparison on education level of farmers in Italian regions in a generic point of view is very low in the agriculture sector.

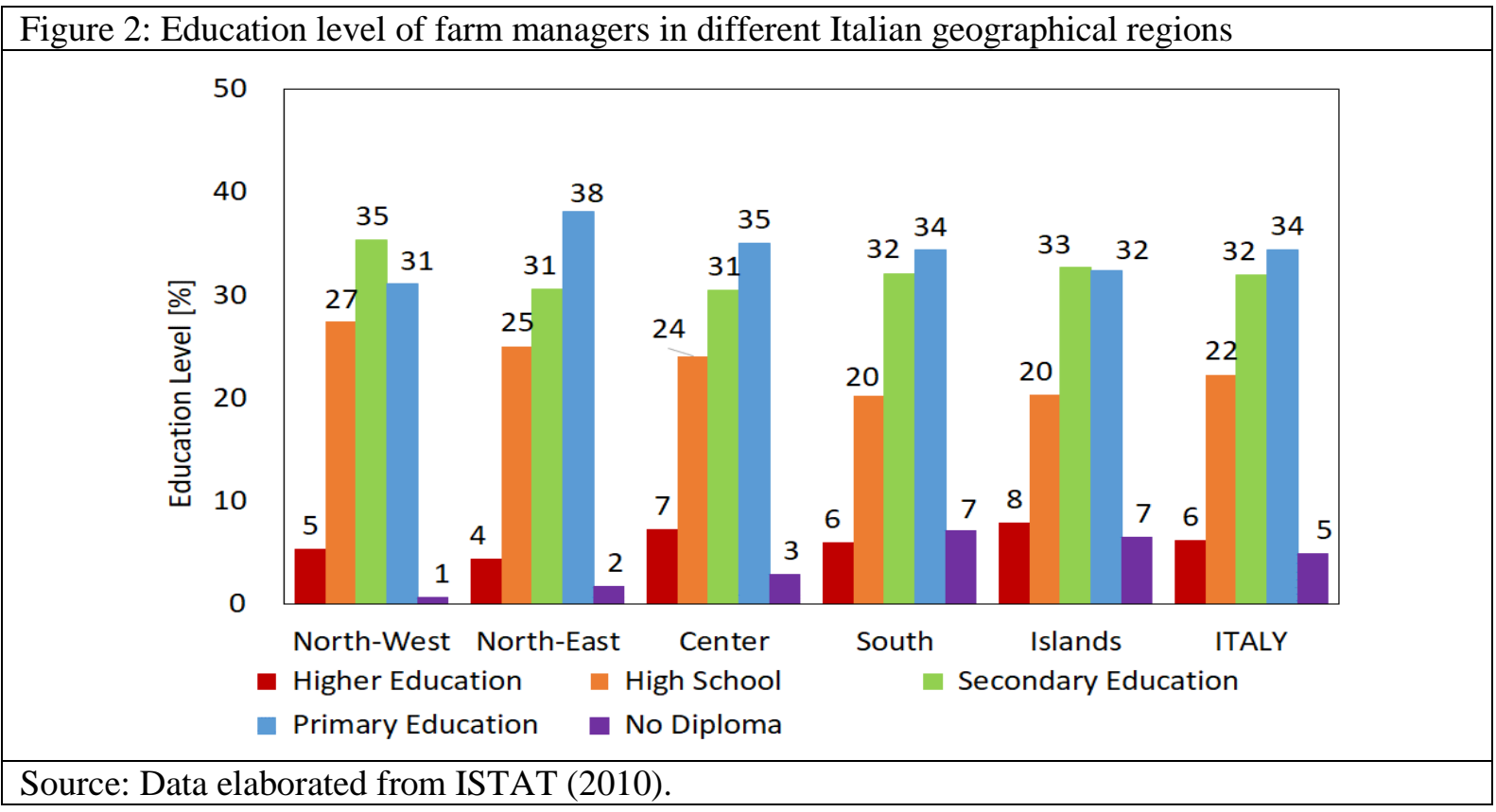

The percentage of farmers with a high education level is only $6 \%$. Primary education and secondary education are the biggest and most representative groups of farmers. 5\% of farmers in Italy have no degree, in this group are included the third age group of 65 years and over.

It is important to mention that the level of education of farmers in Italian regions is low, this is strongly related to the organizational culture background and the integrated system of structures as a basis for the implementation of knowledge management on the agriculture sector. Moreover, scholars have found no relationship (Vanslembrouck et al., 2002) between education and sector performance due to the differences between general education and formal agriculture education, whereas other studies support the theory that the content of the education is crucial in the overall outcome of these processes (Atari et al., 2009). Effectively age links to education via a cohort effect, where experience of farmers is a direct effect of age, and experience and education are connected via the tendency of both to enhance cultural capital and thus socially appropriate courses of action (Burton, 2014). The data above mentioned an average of $34 \%$ in almost all the Italian regions with primary education and secondary education, respectively for 65 years and over. Regional differences on education level are related with the smallscale farm and general traits to development and the opportunities for young farmers in rural areas to apply for substantial economic incentive to make a business. The findings relating to farm size to the number of young sole holders suggests that there could be considerable regional differences; mountainous regions, island regions, for example, are typically characterized by small-scale farming (Pinter \& Kirner, 2014) and may therefore have a lower number of young farmers in other regions.

\section{Conclusions}

The issue of old-new age farming and the low level of education in agriculture brings problems for the future in the agriculture sector in Italian regions and in the European Union. Considering the age of farmers and the level of education, our analysis has demonstrated that, although further research is needed. Even though, our research shows clearly the gap between the first age group (less than 34 years old) with the last age group (65 years old or over) are considered. Of course, the second group "age of farming" how we defined (from 35 to 65 years old), this group is dominant and might fulfil the agreement on social, economic and structural influences on strategic decision-making from the 
European Union in the agriculture sector. The definition of "age of farming" needs to be conceptualized and institutionalized and be accepted in the national level.

This research establishes that there is a close significance between the age of farming and the level of instruction of farmers. We saw that the higher the education level is, the higher the income for the farmers' family. This is important in considering the European Programmes on rising awareness in technological innovation and farmers' participation. Of course, duties on being a farmer holds awareness and awareness is awakened with education. This research illustrates that we need to rethink development strategies, so that we are not only promoting educational campaigns for trained farmers, but rather to encourage enterprise farmers in using new technologies and improving the financial and welfare status of their work. If this aspect were confirmed by the analysis and elaborations from other sources of information, it would pose an interesting question for the purpose of formulating policies. In general, policies such as the Common Agriculture Policies constitute the major tool and prospective to reduce income inequality and gap based on general socio-economic characteristics not attributable to the farmer activity. Social policies (such as those relating to the various aspects of welfare) or aimed at regional convergence in terms of economic development could be equally (if not more) effective and surely the support of income realized in the ambit of sectoral policies should harmonize with them. In particular, information and extension might ensure the participation of farmers with different property situations, cost structures, needs and motivations (Reimer \& Procopy, 2014).

Finally, in terms of secondary objectives for future research, aside from the age and education of farmers in the Italian region, it would be beneficial for example to consider the level of income for age group and education. The European Policy might be interested in knowing this specific data for future programming at the regional level and of course at the national level.

\section{References}

Alphonsus, I., \& Sabran, M. S. (2016). Evaluating the Top-Bottom and Bottom-Up Community Development Approaches: Mixed Method Approach as Alternative for Rural Un-Educated Communities in Developing Countries. Mediterranean Journal of Social Sciences, 7 (4), 266-273.

Atari, D., Yiridoe, E., Smale, S., \& Diunker, P. (2009). What motivates farmers to participate in the Nova Scotia environmental farm plan program? Evidence and environmental policy implications. Journal Environment Management, 90 , 1269-1279.

Best, H. (2009). Organic farming as a rational choice: empirical investigations in environmental decision making. Rationality and Society, 21, 197-224.

Burton, R. J. (2006). An alternative for farmer age as an indicator of life-cycle stage: the case for a farm family age index. Journal of Rural Studies, 22, 485-492.

Burton, R. J. (2014). The influence of farmer demographic characteristics on environmental behaviour: A review. Journal of Environmental Management, 135, 19-26.

Burton, R., \& Wilson, G. (2006). Injecting social psychology theory into conceptualizations of agriculture agency: towards a "post-productivist" farmer self-identity. Journal Rural Study, 22(1), 95-115.

Chiodi, G. (2018). Interpreting Global Land and Water Grabbing through Two Rival Economic Paradigms. Academicus International Scientific Journal, 18, 42-52.

Daci, J. (2012). Protection of the Human Right to Water Under International Law-The Need for a New Legal Framework. Academicus International Scientific Journal, 6, 71-77.

De Rosa, M., Bartoli, L., \& Chiappini, S. (2013). The Adoption of Agricultural Extension Policies in the Italian Farms. New Medit, 20-27.

Dias, C., \& Franco, M. (2018). Cooperation in tradition or tradition in cooperation? Networks of agricultural entrepreneurs. Land use policy, 71 , 36-48.

Earth-Council. (1994). Earth Council: Inter-American Institute for Cooperation on Agriculture (IICA). San Hose, Costa Rica.

EC. (5 de December de 2013). European Commission Overview of CAP Reform 2014-2020. Obtenido de Agricultural Policy Perspectives Brief: https://ec.europa.eu/agriculture/sites/agriculture/files/policy-perspectives/policy-briefs/05_en.pdf: https://ec.europa.eu/agriculture/sites/agriculture/files/policy-perspectives/policy-briefs/05_en.pdf

European Commission. (27 de October de 2015). Obtenido de Council Directive 98/82-Eur-lex.europa https://eurlex.europa.eu/legal-content/EN/TXT/PDF/?uri=CELEX:01998L0083-20151027\&from=EN: https://eur-lex.europa.eu/legalcontent/EN/TXT/PDF/?uri=CELEX:01998L0083-20151027\&from=EN

FAO. (1999). Committee on Agriculture fiftheenth session. Roma: Food Agriculture Organization, Organic agriculture (8).

Fuentes, J., Gallego, E., García, A., \& Ayuga, F. (2010). New uses for old traditional farm buildings: the case of the underground wine cellars in Spain. Land use policy, $27,738-748$. 
Gravsholt Brusck, A. (2002). Farmers landscape decisions: Relationships between farmers values and landscape practices. Sociologia Ruralis.

Hamilton, W., Bosworth, G., \& Ruto, E. (2015). Entrepreneurial younger farmers and the "young farmer problem" in Englang. 1-7.

ISTAT. (20 de Febrary de 2019). Istituto Nazionale di Statistica. Obtenido de Istituto Nazionale di Statistica: https://www.istat.it/: https://www.istat.it/

McCann, E., Sullivan, S., Erickson, D., \& De Young, R. (1997). Environmental awareness, economic orientation, and farming practices: a comparison of organic and conventional farmers. Environmental Management, 21(5), 747-758.

McGuire, J. M., Morton, L. W., Gordon, A. J., \& Cast, A. D. (2015). Farmer identities and responses to the socialbiophysical environment. Journal of Rural Studies, 39, 145-155.

Michael, C. (2016). The Sociology of Food and Agriculture. Second Edition. London: Routledge.

Miftari, A. (2019). Sustainability of water use in agriculture. Southern European farmers participation and social impact. Academicus International Scientific Journal, 19, 131-145.

Moini, G. (2012). Teoria critica della partecipazione. Un approccio sociologico. Roma: Franco Angeli.

Moon, K., Marshall, N., \& C, C. (2012). Personal circumstances and social characteristics as determinants of landholder participation in biodiversity conservation programs. Journal Environment Management, 113, 292-300.

Ondersteijn, C., Giesena, G., \& Huirne, R. (2003). Identification of farmer characteristics and farm strategies explaining changes in environmental management and environmental and economic performance of dairy farms. Agricultural Systems. Vol 78(1), 31-55.

Pinter, M., \& Kirner, L. (2014). Strategies of Disadvantaged mountain dairy farmers as indicatores of agricultural structural change: a case study of Murau, Austria. Land Use Policy, 38, 441-453.

Pugliese, P. (2001). Organic Farming and Sustainable Rural development. A Multifaceted and Promising Convergence. Sociologia Ruralis, 41, 112-130.

RDP. (17 de October de 2015). European Network for Rural Development. Obtenido de 2014-2020 Rural Development Programme: Key facts \& figures: https://enrd.ec.europa.eu/: https://enrd.ec.europa.eu/

Reimer, A., \& Procopy, L. (2014). Farmer participation in U.S: Farm bill conservation programs. Environmnetal Management, 53, 318-332.

Rocchi, B., Stefani, G., \& Romano, D. (2012). Differenze di reddito tra famiglie agricole e non agricole in Italia: una verifica empirica. Agriregionieuropa, 31, 1-10.

Van Rensburg, T., Murphy, E., \& Rocks, P. (2009). Commonage land and farmer uptake of the rural environment protection scheme in Ireland. Land Use Policy, 26, 345-355.

Vanslembrouck, I., Huylenbroeck, G., \& Verbeke, W. (2002). Determinants of the willingness of Belgian farmers to partecipate on agri-environmental measures. Journal Agricultural Economics, 53(3), 489-511.

Zagata, L., \& Sutherland, L.-A. (2015). Deconstructing the "young farmer problem in Europe": Towards a research agenda. Journal of Rural Studies, 38, 39-51.

Zeneli, F. (2016). Analysis of risks and investments' opportunities in water sector. Academicus International Scientific Journal, 13, 128-137. 